\title{
ПРОДУКТИВНОСТЬ И КАЧЕСТВА ЗЕРНА ОЗИМОЙ ПШЕНИЦЫ В ЗАВИСИМОСТИ ОТ ПРЕДШЕСТВЕННИКОВ В УСЛОВИЯХ КРЫМА
}

\author{
Л. А. Радченко, К. Г. Женченко \\ Институт сельского хозяйства Крыма НААН
}

Рассмотрено влияние различных предшественников на наличие влаги в почве, засоренность, урожайность и качество зерна озимой пшеницы в короткоротационных севооборотах в условиях суходола Крыма.

Пшеница озимая, продуктивность, качество, предшественник, стекловидность, клейковина

Пшеница является главным продуктом питания более чем в ста странах мира. Она занимает первое место среди культурных растений по площадям. Площади посева, занимаемые ежегодно пшеницей на Земном шаре, составляют 230-235 млн. га, валовые сборы зерна - до 600 млн. т. На протяжении последнего столетия посевные площади её увеличились вдвое, а производство зерна - в четыре раза. Спрос на пшеничное зерно и продукты его переработки из года в год увеличивается.

На данное время во всем мире, в т.ч. и в нашей стране стоит вопрос о стабилизации площадей посева этой древнейшей культуры при условии увеличения урожайности. В ряде стран площади посева пшеницы даже немного уменьшаются, но валовые сборы растут за счет урожайности. Первое место в мире по урожайности зерна пшеницы на начало 21 века принадлежит Ирландии - 8 т/га, за ней - Великобритания - 7,6 т/га, Нидерланды 7,4 т/га, Дания-7,3 т/га и Германия - 7,2 т/га [1]. Мы такие урожаи имеем в особо благоприятные годы и только на незначительных площадях. В среднем за последние десять лет урожайность озимой пшеницы по Украине составляет 2,9 т/га и по АР Крым - 2,3 т/га.

Для обеспечения роста урожайности озимой пшеницы необходимо повышать эффективность использования потенциальных возможностей сортов и совершенствовать их агротехнику. Большинство районированных сортов имеют потенциальную урожайность до 10 т/га и выше. Наша задача, учитывая биологические особенности культуры и сорта, применять соответствующую технологию выращивания.

Начинать следует с места озимой пшеницы в севообороте, т. е. из предшественников. Известно, что в Степи Украины влияние предшественников на урожайность данной культуры проявляется особенно сильно в

(C) Л. А. Радченко, К. Г. Женченко. 2013.

ISSN 0582-5075. Селекція і насінництво. 2013. Випуск 103. 
связи с недостаточным количеством осадков, следовательно, с лимитированным содержанием продуктивной влаги в почве. Предшественники всегда оказывали значительное влияние на величину и качество урожая, а в последнее десятилетие, при усугублении неблагоприятных погодных условий (уменьшение количества хозяйственно-полезных осадков, повышение температуры воздуха и почвы, увеличение количества дней со скоростью ветра 15 и более метров в секунду и прочие климатические отклонения от нормы), они стали одним из решающих факторов.

Почвенно-климатические условия степного Крыма предполагают получение не только рентабельного урожая озимой пшеницы при качественном и своевременном соблюдении всех агротребований, но и зерна высокого качества.

Цель исследований. Определить роль предшественников в повышении урожайности и качества зерна озимой пшеницы в степной зоне Крыма.

Условия и методика исследований. Озимую пшеницу высевали по различным предшественникам в типичных для степной зоны зернопаропропашных севооборотах Института сельского хозяйства Крыма НААН в течение 2007-2012 гг.

Почва расположения стационара - южные малогумусные среднемощные черноземы с содержанием гумуса 2,0 - 2,3\%, с недостаточным количеством подвижной фосфорной кислоты, но достаточно обеспеченные калием. Обеспеченность растений подвижным азотом связана с процессами нитрификации и, несмотря на благоприятные условия, крымские почвы нуждаются в пополнении запасов азота. По механическому составу они преимущественно иловато-пылеватые легкие глины. В южных черноземах большой запас воды является мертвым, недоступным для растений [2].

Климат равнинного Крыма степной, засушливый, континентальный. Амплитуда температур: абсолютный максимум $+37-+39^{0} \mathrm{C}$ и абсолютный минимум $-32-37^{0}$ С. Крым находится под воздействием многообразных климатических факторов, среди которых существенную роль играет ветер: его направление, сила, продолжительность обуславливают температурную и водную характеристики года и сказываются на микроклимате [3]. Последние два десятилетия климат степного Крыма меняется не в лучшую сторону. Годовая сумма осадков 428 мм. Наибольшая влажность почвы приходится на зимне-весенний период, наименьшая - лето-осень [4].

Характеризуя годы проведения исследований, пришли к выводу, что наименышее количество осадков было в предпосевной и посевной периоды. В оптимальный срок посева озимой пшеницы количество продуктивной влаги в метровом горизонте было недостаточным, а в посевном и пахотном или недостаточным или она совсем отсутствовала, при этом температура почвы на глубине заделки семян была значительно выше рекомендуемой. Зимы за годы исследований были относительно теплыми, за исключением февраля 2012 г.

Из шести лет исследований в послеуборочный период (июль-октябрь) только два года (2007 и 2010 гг.) количество осадков было близким к норме 
136,8-140,8 мм, все остальные меньше - 116,1 - 86,2 мм, при среднемноголетнем показателе за этот же период - 134 мм.

Весной 2007, 2009, 2010, и 2011 гг. количество осадков было около нормы, в 2008 - больше нормы (141,3 мм), а в 2012 г. - 81,6 мм, что значительно меньше среднемноголетнего показателя (101 мм).

Летние периоды 2007-2009 гг. и 2012 г. были жаркими и без осадков, а в 2010 г. и 2011 г. осадки выпадали в предуборочный и уборочный периоды озимой пшеницы, что отрицательно повлияло на урожайность и качество зерна.

Подготовка почвы под посев проводилась по рекомендованным технологиям в зависимости от предшественников: вспашка паров; мелкое и поверхностное рыхление после других предшественников. Органические удобрения вносили в парах из расчета 7 т на 1 га севооборотной площади, минеральные удобрения одноразово под основную обработку почвы. Опыт закладывался в трех повторностях. Общая площадь делянок $160 \mathrm{~m}^{2}$, учетная

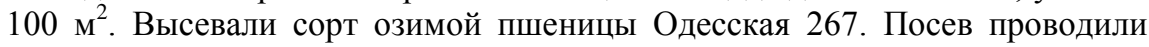
сеялкой СН-16, уборку урожая комбайном Сампо 130. Наблюдения и учёты проводили на основании общепринятых методик.

Результаты исследований. Посев озимой пшеницы проводили в III декаде октября, когда температура воздуха и почвы на глубине заделки семян приближались к оптимальным - $16-18^{0} \mathrm{C}$ и $10-12^{0} \mathrm{C}$, соответственно [5].

Для озимой пшеницы одним из основных показателей надежности предшественника в нашей зоне является количество продуктивной влаги, которое имеется в почве ко времени ее оптимального срока сева.

Надо заметить, что наличие влаги в почве зависит не столько от предшествующей культуры, сколько от погодных условий периода, предшествовавшего посеву, и в первую очередь от количества выпадающих осадков. Количество продуктивной влаги в почве в зависимости от предшественников за годы проведения опытов представлены в таблице1.

В первой ротации севооборота наиболее засушливый предпосевной период отмечался осенью 2009 года, когда в посевном и пахотном слоях, независимо от предшествующей культуры, продуктивная влага практически отсутствовала. После прошедших осадков (за осень две нормы в сравнении с многолетними данными) количество влаги под урожай 2011 г. было независимо от предшественников одинаково высоким - 23,8-26 мм. В другие годы наблюдалась разница в наличии влаги в зависимости от предшественника: по чистым парам в пахотном слое (0-20 см) было 13,8-14 мм продуктивной влаги, после стерневых в этом же слое всего 4,2-12 мм.

Накопление влаги в метровом горизонте зависит в большей степени от предшественника и разница бывает довольно значительная: в наших опытах в среднем за первую ротацию продуктивной влаги по чистому пару было 58,8 мм, после занятого пара 33,1-37,4 мм, после нута, горчицы 30,0 и 35,7 мм, и наименьшее количество после рапса и стерневых 27,7 и 25,1 мм соответственно. 
Таблица 1

Наличие влаги в почве в период посева озимой пшеницы в зависимости от предшественников, мм

\begin{tabular}{|c|c|c|c|c|c|c|c|c|c|c|c|c|c|c|}
\hline \multirow{3}{*}{$\begin{array}{c}\text { Предшествен- } \\
\text { ник }\end{array}$} & \multicolumn{14}{|c|}{ Год } \\
\hline & \multicolumn{2}{|c|}{2007} & \multicolumn{2}{|c|}{2008} & \multicolumn{2}{|c|}{2009} & \multicolumn{2}{|c|}{2010} & \multicolumn{2}{|c|}{2011} & \multicolumn{2}{|c|}{$\begin{array}{c}\text { Среднее за } \\
\text { I ротацию }\end{array}$} & \multicolumn{2}{|c|}{$\begin{array}{c}2012 \text { г. } \\
\text { II ротация }\end{array}$} \\
\hline & ્ֻત & $\frac{8}{1}$ & ্ֻণ & $\frac{8}{1}$ & ્ֻત & $\frac{8}{1}$ & 옹 & $\frac{8}{d}$ & ণิ & $\frac{8}{1}$ & 오 & $\frac{8}{1}$ & ণิ & $\frac{8}{0}$ \\
\hline Пар черный & 13,9 & 55,7 & 14,0 & 61,6 & 13,8 & 76,0 & 0,4 & 8,9 & 24,8 & 91,9 & 13,4 & 58,8 & 12,9 & 56,2 \\
\hline $\begin{array}{l}\text { Пар занятый } \\
\text { (яровые з/б) }\end{array}$ & 13,8 & 54,5 & 11,9 & 40,6 & 9,4 & 26,8 & 0 & 0,3 & 24,9 & 79,5 & 12,0 & 33,1 & 8,0 & 38,7 \\
\hline $\begin{array}{l}\text { Пар занятый } \\
\text { (озимые з/б) }\end{array}$ & 12,7 & 46,8 & 8,6 & 30,5 & 11,2 & 18,1 & 0 & 0,2 & 24,6 & 91,6 & 11,4 & 37,4 & 13,0 & 38,9 \\
\hline Горчица & 13,6 & 44,4 & 9,5 & 36,1 & 9,3 & 21,3 & 0 & 0 & 26,0 & 76,9 & 10,6 & 35,7 & 10,2 & 32,0 \\
\hline Нут & 11,8 & 39,1 & 7,4 & 23,9 & 10,2 & 20,6 & 0 & 0,3 & 23,8 & 66,2 & 11,3 & 30,0 & 10,9 & 22,6 \\
\hline Рапс озимый & 10,1 & 35,7 & 4,3 & 6,1 & 11,1 & 30,9 & 0 & 1,9 & 25,4 & 71,8 & 10,2 & 27,7 & 9,9 & 27,1 \\
\hline Стерня & 8,4 & 26,9 & 4,2 & 5,5 & 12,0 & 27,0 & 0 & 1,4 & 24,2 & 64,6 & 9,8 & 25,1 & 9,7 & 10,5 \\
\hline
\end{tabular}


Низкое содержание влаги в метровом слое почвы под рапсом и стерневым предшественником дает основание некоторым ученым считать их условно допустимыми или вообще недопустимыми предшественниками под озимую пшеницу.

Под урожай 2012 г. за период, предшествовавший посеву, выпало наименьшее количество осадков, и разница в количестве влаги в слое 0 100 см в зависимости от предшественников была еще более значительная. Если наличие влаги в чистом пару (56,2 мм) принять за $100 \%$, то в занятых парах ее было 69 \%, после горчицы 57 \%, после других пропашных 44 \%, а после стерневых всего $19 \%$, т.е. в пять раз меньше.

За зимний и ранневесенний периоды, как правило, запасы влаги в почве пополняются. При возобновлении вегетации озимых, в среднем за первую ротацию севооборота, в пахотном слое продуктивной влаги было по всем вариантам посева озимой пшеницы одинаково высокое количество 20,1-22,7 мм, а в метровом до 100 мм. Исключение составили данные по продуктивной влажности в 2012 г., когда к моменту возобновления вегетации в пахотном слое после лучших предшественников было 16,8-19,5 мм, после худших всего 7,7-10,7 мм (редкий случай). Значительная разница и в накоплении влаги в метровом горизонте от лучших до недопустимых предшественников - 84 и 29,8 мм соответственно.

Сорняки растут на полях в сообществе с культурными растениями и озимая пшеница не является исключением. В нашем стационаре ее посевы сопровождают озимые и зимующие сорняки (хориспора нежная, гулявник высокий, яснотка стеблеобъемлющая, ярутка полевая) и ранние яровые (вероника плющелистая, дымянка аптечная).

При вхождении в севооборот количество сорняков было довольно значительным после всех предшественников и разница была большая: по пару чистому $-188 ш \mathrm{~m} / \mathrm{m}^{2}$, после рапса -225 шт/м², после всех других от 322 до 384 шт/м² или в 1,7-2 раза больше, чем на паровом поле (табл. 2).

В среднем за I ротацию наименьшее количество сорняков было в посевах озимой пшеницы по чистому пару и после рапса - 137 и 126 шт/м², наибольшее после паров занятых - 222 и 314 шт/м² (сказывается, что на парах, занятых злакобобовыми смесями, не применяются гербициды). Горчица, нут и стерня в наших опытах как предшественники озимой пшеницы по влиянию на засоренность оказались равнозначными - 171-186 шт/ $\mathrm{m}^{2}$.

Применение химической защиты для уничтожения сорняков обычно срабатывало отлично и к уборке посевы озимой пшенице были практически чистыми, независимо от предшествующей культуры.

Исключение составил 2010 г., когда майские осадки в количестве 77,5 мм спровоцировали вторую волну сорняков и их количество было от 15 до 73 шт/м².

В 2012 г. количество сорняков было незначительным, так как жесточайшая засуха значительно угнетала и их развитие.

Для уничтожения сорняков в фазу кущения озимой пшеницы применяли баковые смеси гербицидов. В течение первой ротации количество сорной растительности постепенно снижалось и к 2011 г. в посевах озимой пшеницы было зафиксировано наименьшее количество сорняков за весь период исследований. 
Таблица 2

Влияние предшественников на наличие сорной растительности в посевах озимой пшеницы, шт/м².

\begin{tabular}{|c|c|c|c|c|c|c|c|c|c|c|c|c|}
\hline \multirow[b]{2}{*}{$\begin{array}{c}\text { Предшествующая } \\
\text { культура }\end{array}$} & \multicolumn{12}{|c|}{ Год } \\
\hline & 2007 & 2008 & 2009 & 2010 & 2011 & $\begin{array}{c}\text { среднее } \\
\text { за I } \\
\text { ротацию }\end{array}$ & 2007 & 2008 & 2009 & 2010 & 2011 & \begin{tabular}{|c} 
среднее \\
за I \\
ротацию
\end{tabular} \\
\hline \multicolumn{8}{|c|}{ Фаза кущения (озимые), всходы (яровые) } & \multicolumn{5}{|c|}{ Уборка } \\
\hline Чистый пар & 188 & 150 & 103 & 206 & 36 & 137 & 1,0 & 2,8 & 0 & 33 & 0,4 & 7,4 \\
\hline Занятый пар (яровые з/б) & 375 & 304 & 133 & 257 & 42 & 222 & 1,0 & 6,3 & 0 & 45 & 1,3 & 10,7 \\
\hline Занятый пар (озимые з/б) & 384 & 579 & 217 & 316 & 76 & 314 & 1,3 & 3,3 & 0 & 63 & 0 & 13,5 \\
\hline Горчица & 338 & 203 & 137 & 203 & 35 & 183 & 2,3 & 11 & 0 & 36 & 1,3 & 10,1 \\
\hline Нут & 363 & 190 & 153 & 187 & 38 & 186 & 0 & 7 & 0,3 & 73 & 1,0 & 16,3 \\
\hline Рапс & 225 & 136 & 87 & 124 & 60 & 126 & 17 & 16 & 0 & 15 & 12 & 12 \\
\hline Стерневые & 322 & 190 & 83 & 215 & 46 & 171 & 21 & 19 & 0 & 48 & 1,3 & 17,8 \\
\hline
\end{tabular}


Это результат агротехники, четкого соблюдения чередования культур в севообороте и благоприятных условий года. Для посевов озимой пшеницы сочетание значительного количества осадков с осени и благоприятный тепловой режим в течении осень-зима были насколько оптимальными, что культурные растения составили существенную конкуренцию сорнякам. В связи с тем, что их количество не превышало порога вредоносности, посевы озимой пшеницы в химзащите не нуждались. По мнению ряда ученых, полное уничтожение сорняков не обязательно, а снижение химической нагрузки не только экономически выгодно, но и эффективно для охраны окружающей среды [6].

Урожайность озимой пшеницы по чистому пару в 2008 г. и 2011 г. была высокой и достигала 5,96 т/га и 6,74 т/га соответственно (табл. 3).

Таблица 3

Урожайность озимой пшеницы в зависимости от предшественников, т/га.

\begin{tabular}{|l|c|c|c|c|c|c|c|}
\hline \multirow{2}{*}{$\begin{array}{c}\text { Предшествен- } \\
\text { ник }\end{array}$} & 2007 & 2008 & 2009 & 2010 & 2011 & $\begin{array}{c}\text { среднее за } \\
\text { І ротацию }\end{array}$ & $\begin{array}{c}\text { 2012 г. II } \\
\text { ротация }\end{array}$ \\
\cline { 2 - 8 } & 4,72 & 5,96 & 3,91 & 2,83 & 6,74 & 4,83 & 1,65 \\
\hline Пар черный & 4,06 & 5,11 & 3,01 & 2,63 & 5,92 & 4,15 & 1,32 \\
\hline $\begin{array}{l}\text { Пар занятый } \\
\text { яровые з/б) }\end{array}$ & 4,12 & 4,81 & 2,98 & 2,07 & 6,14 & 4,02 & 1,25 \\
\hline $\begin{array}{l}\text { Пар занятый } \\
\text { (озимые з/б) }\end{array}$ & 4,19 & 3,94 & 3,32 & 2,01 & 6,39 & 3,97 & 0,64 \\
\hline Горчица & 4,23 & 3,65 & 3,23 & 2,43 & 6,12 & 3,93 & 0,90 \\
\hline Нут & 2,13 & 3,84 & 2,89 & 3,06 & 6,54 & 3,69 & 0,53 \\
\hline Рапс озимый & 2,02 & 3,61 & 2,52 & 1,98 & 6,31 & 3,29 & 0,59 \\
\hline Стерневые & & & & & & \\
\hline
\end{tabular}

Это были наиболее благоприятные годы, но даже в 2008 г. разница в урожайности по предшественникам была значительной. Снижение урожайности после непаровых предшественников было на 34-40 \%. В 2011 году урожайность в зависимости от предшественников была одинаково высокой. За І-ю ротацию севооборота снижение урожайности озимой пшеницы после других предшественников в сравнении с паром составило от 0,68 т/га до 1,54 т/га. Значительная разница по урожайности получена в 2012 г., первый год второй ротации. В связи с жесточайшей засухой в течение всей вегетации озимой пшеницы по черному пару получили урожайность 1,65 т/га, после занятых паров - 1,25-1,32 т/га; после непаровых от 0,90 до 0,59 т/га. После стерневых урожайность пшеницы в сравнении с чистым паром снизилась в 2,8 раза или на $64 \%$.

Для оценки влияния предшественников на качество зерна озимой пшеницы в опытах определялись показатели стекловидности и количества сырой клейковины. Их зависимость от предшественников представлена в таблице 4. 
Таблица 4

Качество зерна озимой пшеницы в зависимости от предшественников, \%

\begin{tabular}{|l|c|c|c|c|c|c|c|c|c|c|c|c|c|c|c|}
\hline \multirow{2}{*}{ Предшественник } & 2007 & 2008 & 2009 & 2010 & 2011 & Среднее & 2007 & 2008 & 2009 & 2010 & 2011 & Среднее \\
\cline { 2 - 13 } & \multicolumn{6}{|c|}{ Стекловидность } \\
\hline \multirow{8}{\text{Парчерный}}{} & 51,6 & 74,1 & 92,8 & 72,3 & 86,8 & 75,5 & 25,6 & 28,9 & 45,6 & 23,6 & 29,6 & 30,7 \\
\hline $\begin{array}{l}\text { Пар занятый } \\
\text { (яровые з/б) }\end{array}$ & 36,7 & 69,5 & 96,7 & 68,5 & 83,5 & 70,9 & 23,4 & 26,4 & 35,0 & 21,6 & 25,6 & 26,4 \\
\hline $\begin{array}{l}\text { Пар занятый } \\
\text { (озимые з/б) }\end{array}$ & 38,2 & 70 & 94,2 & 70,0 & 90,5 & 72,6 & 26,2 & 28,6 & 43,2 & 22,2 & 25,6 & 29,2 \\
\hline Горчица & 46,0 & 63,2 & 95,7 & 69,2 & 86,5 & 72,1 & 24,8 & 27,8 & 32,2 & 23,2 & 22,8 & 26,2 \\
\hline Нут & 41,2 & 67,7 & 95,0 & 71,2 & 85,2 & 72,1 & 23,0 & 22,8 & 33,6 & 23,2 & 22,8 & 25,1 \\
\hline Озимый рапс & 32,2 & 52,7 & 92,9 & 63,2 & 66,9 & 61,6 & 22,1 & 24,6 & 36,7 & 18,6 & 25,0 & 25,4 \\
\hline Стерня & 35,7 & 49,8 & 92,5 & 56,0 & 55,0 & 63,3 & 23,6 & 20,8 & 30,2 & 16,0 & 17,2 & 21,0 \\
\hline
\end{tabular}


Стекловидность зерна по чистому пару, в зависимости от условий года, составляла от 51,6 до 92,8 \%, в среднем за пять лет - 75,5\%. Примерно на таком же уровне была стекловидность зерна озимой пшеницы, выращенной после занятых паров, нута и горчицы (в среднем 71,9\%), и более низкой - после стерневых и рапса - 63,3 и $61,6 \%$ соответственно.

Зерно озимой пшеницы при содержании в нём сырой клейковины 23-30 \% относится к продовольственному классу. По нашим данным, наибольшее содержание клейковины в зерне пшеницы, посеянной по чистому пару (в среднем за годы исследований 30,7 \%). После других предшественников этот показательнаходился в пределах 25,1 - 29,2 \%, что позволяет выращенное зерно отнести к продовольственному. Исключение составляет пшеница, выращенная после стерневых, у которой средний показатель количества сырой клейковины в зерне всего $21 \%$.

Выводы. Лучшими предшественниками озимой пшеницы по накоплению влаги, снижению засорённости полей, а следовательно, по урожайности и качеству продукции являются чистые и занятые пары. Худшие по этим же параметрам предшественники - стерневые. Пропашные, в частности нут, горчица, рапс - занимают промежуточное положение.

\section{Список использованных источников}

1.Пшеница: история, морфология, биология, селекция / [В. В. Шелепов, Н. П. Чебаков, В. А. Вергунов, В. С. Кочмарский] (под ред. В. В. Шелепова, Н. П. Чебакова). - Мироновка: Мироновская типография, 2005.- 580 с. 2.Дзенс-Литовская Н. Н. Почвы и растительность степного Крыма / Н. Н. Дзенс-Литовская. - Л.: Наука, 1970. - 157 с.

3.Богдан П. И. Пшеницы Крыма / П. И. Богдан. - М.:Советская наука, 1941.-199 c.

4. Агрокліматичний довідник по Автономній Республіці Крим (19862005 рр.) / За ред. О. І. Прудка, Т. І. Адаменко. - Сімферополь: «Таврида», 2011. - 343 с.

5.Носатовский А. И. Пшеница / А. И. Носатовский. - М.: Колос, 1965. $568 \mathrm{c}$.

6. Либман $М$. Устойчивость сорняков к гербицидам и разработка гербицидов / М. Либман // Агроном - 2010.-№ 1.-С. 50. 